\title{
Bentuk, Fungsi, dan Distribusi Reduplikasi Kata Benda Bahasa Melayu dan Bahasa Jepang
}

\author{
${ }^{1}$ Shyi Nian Ong, ${ }^{2}$ Zaitul Azma Zainon Hamzah \\ 1Universiti Malaya, Malaysia \\ 2Universiti Putra Malaysia, Malaysia \\ 1ongsn@um.edu.my \\ 2zazh@upm.edu.my
}

DOI: $10.18196 /$ jjlel.4134

\begin{abstract}
Abstrak
Reduplikasi adalah proses menggandakan kata di mana banyak kata baru dapat dihasilkan melalui proses reduplikasi dan proses ini memiliki fungsi leksikal di mana ia dapat mempertahankan kelas kata yang mempertahankan kelas atau mengubah kelas (class-changing) seperti yang dijabarkan oleh Asmah (2001: 17-35) yang menyatakan bahwa "Reduplication has a lexical function; that is to say it derives new words from the root-forms." Tujuan dari penelitian ini adalah membuat deskriptif kualitatif nomina reduplikasi kontrasif yang ada dalam bahasa selain bahasa Inggris dan Jepang. Perbandingan antara kedua bahasa dilakukan untuk memeriksa persamaan dan perbedaan fungsi atau reduplikasi kata benda dalam bahasa Melayu dan Jepang. Data diambil dari literatur seperti Takayama (2012), Osato (2013), Kobayakawa (2004), Tamura (1991) dan Matsumoto (2009) untuk sumber Bahasa Jepang dan Asmah (1975) dan Abdullah (1974) untuk bahasa Melayu dan dianalisis dengan membandingkan elemen persamaan dan perbedaan yang ada di kedua bahasa. Temuan yang menarik adalah kata hito (orang) dalam bahasa Jepang menjadi hito-bito (orang), yang menunjukkan perubahan konsonan / h / ke / b / dalam suku kata pertama, yang dapat dikategorikan sebagai reduplikasi dengan perubahan suara. Demikian pula dengan bahasa Melayu, ada perubahan pada bunyi konsonan seperti piring, di mana / l / a / r / atau sayuran / s / a / m /, saat jamak.
\end{abstract}

Kata kunci: kontras; reduplikasi; kata benda; Melayu; Jepang

\begin{abstract}
Reduplication is a process of multiplying words in which many new words can be generated, and the process has a lexical function that can maintain the classmaintaining or class-changing (word-changing) of a word, as asserted by Asmah (2001: 17-35) that "Reduplication has a lexical function; that is to say it derives new words from the root-forms". This study aims to make reduplication of contrasting qualitative descriptive nouns existing in languages other than English and Japanese. The comparisons were carried out between the two
\end{abstract}


languages aiming to examine similarities and differences in function or reduplication of nouns in both Malay and Japanese. The data were taken from the libraries, such as Takayama (2012), Osato (2013), Kobayakawa (2004), Tamura (1991) and Matsumoto (2009) for the Japanese, and Asmah (1975) and Abdullah (1974) for the Malay, and analyzed by comparing elements of similarities and differences existing in both languages. Among the interesting findings is the name word "hito" (person) in Japanese to "hito-bito" (people), showing the change of consonant / $h /$ to / $b$ / in its first syllable, which can be categorized as reduplication with the change of sound. Likewise with Malay, there is a change in the consonant sounds in "lauk pauk", in which / l / becomes $/ p /$ and in "sayur-mayur" / $/$ / becomes / $m$ / when pluralized.

Keywords: contrastive; reduplication; noun; Malay; Japanese

\section{PENDAHULUAN}

Kajian morfologi mencakup semua elemen yang terkait dengan proses pembentukan kata; termasuk penerbitan, pengunduhan, reduplikasi, dan proses penemuan. Proses pembentukan kata dalam bahasa apapun adalah cara yang produktif untuk menciptakan kata-kata baru dari kata-kata yang sudah ada dalam bahasa tersebut.

Reduplikasi adalah proses yang biasanya ada dalam bahasa Melayu, Jepang dan beberapa bahasa lainnya, dan ini adalah salah satu dari enam jenis tata bahasa utama yang disebutkan oleh Sapir selain urutan kata-kata, komposisi, afiksasi, renovasi interior radikal atau tata bahasa dan perbedaan aksen. Proses ini juga digunakan dalam berbagai bentuk untuk mencapai berbagai tujuan leksikal, morfologis dan tata bahasa (Dineen, 1967: 228). Dalam studi sastra, ada istilah lain yang kadang-kadang digunakan secara bergantian dengan pengulangan seperti kloning, penggandaan, duplikasi, dan pengulangan tetapi istilah reduplikasi digunakan dalam penelitian ini. Reduplikasi adalah proses pengulangan kata atau elemen kata. Reduplikasi juga merupakan proses pengurangan kata dengan pengulangan utuh maupun sebagian seperti lelaki, sayur-mayur, dan sebagainya. Dalam bahasa Melayu, ada beberapa jenis reduplikasi berdasarkan fonologi, morfologi, sintaksis, tata bahasa, dan sebagainya (lihat Tabel 1). 
Menurut Tatabahasa Dewan Edisi Ketiga (2015), reduplikasi atau duplikasi dapat dibagi menjadi tiga kategori utama. Duplikasi penuh adalah pengulangan seluruh kata dasar dari jenis kata tanpa perubahan bentuk (misalnya, buku-buku dan sekolah-sekolah). Yang kedua adalah penggandaan parsial yang hanya melibatkan beberapa kata dasar (misalnya, gegelang, sesiku dan sesumbu). Ketiga adalah penggandaan multipel/ritmik yang menggandakan kata dasar dari jenis kata sesuai dengan ketukan suara spesifik dalam kata dasar (misalnya, kuih-muih, kayu-kayan, dan saudara-mara). Kata imbuhan ganda adalah menambahkan awalan ke kata dasar yang diulang seperti beramai-ramai.

Reduplikasi adalah proses morfologis yang menghasilkan kata-kata dengan mengulangi beberapa atau semua elemen yang terkandung dalam kata dasar. Reduplikasi juga sering disebut sebagai penggandaan (doubling) dan kata-kata yang dihasilkan dari proses reduplikasi disebut sebagai kata reduplikasi. Biasanya, kata ganda ditulis menggunakan tanda hubung (-) kecuali reduplikasi parsial dari satu kata. Selain itu, kata ganda juga ditulis tanpa tanda hubung untuk situasi di mana kedua kata dapat berdiri sendiri (misalnya, asal usul). Kata ganda lain seperti huru-hara tidak dapat ditulis tanpa tanda hubung karena 'huru' tidak memiliki arti yang khas dalam bahasa Melayu.

Menurut Hall (1964: 135), proses tata bahasa dapat melibatkan memodifikasi satu bentuk dalam beberapa cara, atau menggabungkan lebih dari satu bentuk. Dalam hal ini, morfologi prosodik menekankan proses fonologis termasuk pengulangan yang membedakan dasar (yaitu, elemen tetap) dari yang disalin (yaitu, elemen berulang). Proses dan makna yang melekat dalam bahasa tertentu tidak secara alami terhubung. Reduplikasi melibatkan unit prosodik (dimulai dengan fonem dan berakhir dengan morfem) atau kata-kata yang diulang. Dengan kata lain, semua atau sebagian elemen dasar diulang. Oleh karena itu, ini adalah proses pengulangan (Dineen, 
1967: 228; Matthews, 1974: 127; Richard et al, 1985: 241; Naples, 1996: 171; dan Yule, 2006: 249).

Proses ini disebut reduplikasi karena kata kedua mengikuti kata pertama untuk menekankannya. Oleh karena itu, kata kedua tidak dapat diucapkan sendiri tanpa kata pertama. Proses ini dianggap sebagai pembentukan tata bahasa tertentu atau fenomena morfologis pemersatu, serangkaian unit yang saling terkait di mana kata baru dihasilkan dengan mengulangi morfem disertai dengan perubahan vokal atau konsonan awal (Robins, 1967: 212-3; Stageberg, 1981: 127; Katamba (1993: 187); Katamba dan Stonham (2006: 177); Matthews, 2007: 337).

Komponen reduplikasi terdiri dari setidaknya dua bentuk linguistik yang disusun dalam urutan paradigmatik, yang merupakan hubungan morfologis yang tidak lengkap. Bentuk kedua melibatkan segmen atau urutan segmen yang diperoleh dengan pengulangan daripada pengulangan bagian pertama (Verma dan Krishnaswamy, 1989: 71; Trask, 1993: 231-2; Fromkin et al, 2003: 112; Davies dan Catherine, 2007: 38).

Ada dua pandangan berbeda tentang reduplikasi. Pandangan pertama menunjukkan bahwa ini adalah proses dimana bentuk-bentuk fonologis disalin, yang merupakan isi dari elemen-elemen yang diulangi oleh berbagai kendala fonologis (Marantz, 1982; McCarthy dan Prince, 1986 dalam Ghomeshi et al., 2004: 341). Yang kedua menjelaskan bahwa ini adalah proses dimana sintesis morfosintaktis (morfosintaktis) yang disalin (Inklass dan Zoll 2000 qtd dalam ibid).

Katamba (1993 dan 2006) menganggap reduplikasi sebagai proses afiksasi yang melibatkan penambahan morfem bebas (tidak harus morfem) di awal, akhir atau di antara akar. McCarthy (1983: 25), Katamba dan Stonham (2006: 184) menganggap reduplikasi sebagai kasus khusus keteraturan morfologis, di mana remunerasi secara fonologis tidak jelas dengan menerima ekspresi fonetis penuh mereka dengan menyalin elemen-elemen yang berdekatan. 


\section{JOURNAL OF \\ EDUCATION \& \\ LINGUISTICS}

Reduplikasi digunakan dalam beberapa bahasa untuk berbagai keperluan. Ini dapat dimodifikasi dalam dua cara sebagai proses atau sebagai tambahan. Proses ini dianggap sebagai cara umum untuk mendefinisikan kata benda. Dalam bahasa Melayu, ada banyak jenis pengulangan dalam struktur yang dikatakan bentuk yang sempurna (Crystal, 1992: 329; 2003: 391).

Reduplikasi dapat berbentuk kata benda, kata kerja, dan kata sifat. Secara umum, pengganda digunakan untuk menunjukkan properti jamak. Secara umum, jika kata benda (misal, se-, semua, separuh) hadir di depan kata benda, maka tidak perlu melalui proses multiplikasi. Jadi, untuk frasa 'semua murid', dan 'murid' tidak perlu melalui proses perkalian karena sifat jamak mereka dapat dilihat dalam istilah numerik. Selain itu, proses duplikasi untuk kata kerja memiliki fungsi yang berbeda. Di antara fungsi-fungsi ini adalah untuk menggambarkan tindakan retribusi (contohnya,tolong-menolong), menunjukkan perbuatan yang berulang-ulang (contoh, menepuk-nepuk), perbuatan yang bersungguh (contohnya, teresak-esak) dan perbuatan yang berlanjutan selama sesuatu jangka masa (contohnya, baring-baring). Banyak kata sifat dengan kata sifat digunakan untuk menekankan kata sifat (contohnya, hura-hara) dan untuk persamaan kata sifat (contohnya, kemerahmerahan).

Bentuk, bentuk atau sifat kata sifat dalam konsep konsep istilah yang dimaksud adalah benda atau benda yang memiliki sifat, bentuk atau penampilan yang identik dalam penampilan, bentuk dan sifat yang identik dengan kata dasarnya. Contohnya, jejari, bebola, dan cecair yang dibentuk dari kata dasar jari, bola, dan cair. Kata ulang jejari diistilahkan karena rupanya menyerupai jari, tetapi bukan jari yang sebenarnya; begitu juga dengan bebola, karena rupanya bulat seperti bola dan cecair karena sifatnya yang cair dan mengalir seperti air.

Dalam beberapa bahasa, reduplikasi digambarkan sebagai proses pembentukan kata di mana awalan dibuat dengan mengulangi konsonan pertama dan vokal dasar. Pada dasarnya, vokal [+ panjang] menjadi [yang 
terpanjang] dalam awalan sistematis (Falk, 1978: 141-2). Selain itu, reduplikasi juga dapat digunakan untuk merujuk pada pengulangan, aktivitas kustom dan frekuensi tindakan atau peristiwa yang ditemukan dalam kata kerja, peningkatan ukuran dan peningkatan intensitas yang digunakan untuk merujuk pada makna argumentatif yang didukung oleh reduplikasi. Ini juga mengungkapkan ambiguitas, distribusi (masing-masing X), kontinuitas, aspek kebiasaan, keragaman dan kesetaraan, di samping berbagai macam makna turunan (Katamba dan Stonham, 2006: 180-1).

\begin{tabular}{|lll|}
\hline Jenis Reduplikasi & \multicolumn{1}{c|}{ Deskripsi } & \multicolumn{1}{c|}{ Contoh } \\
\hline $\begin{array}{l}\text { Reduplikasi } \\
\text { fonologi }\end{array}$ & $\begin{array}{l}\text { Pengulangan fonem tanpa banyak } \\
\text { mengubah arti dan berbunyi sama }\end{array}$ & buku-buku \\
\hline $\begin{array}{l}\text { Reduplikasi } \\
\text { morfologi }\end{array}$ & Pengulangan morfem & papa, mama \\
\hline $\begin{array}{l}\text { Reduplikasi } \\
\text { sintaksis }\end{array}$ & $\begin{array}{l}\text { Pengulangan morfem } \\
\text { menghasilkan klausa }\end{array}$ & yang \\
\hline $\begin{array}{l}\text { Reduplikasi } \\
\text { gramatikal }\end{array}$ & $\begin{array}{l}\text { Pengulangan fungsi dari bentuk kata } \\
\text { dasar yang meliputi morfologi dan } \\
\text { sintaksis }\end{array}$ & terkial-kial \\
\hline $\begin{array}{l}\text { Reduplikasi } \\
\text { idiomatis }\end{array}$ & $\begin{array}{l}\text { Pengulangan kata dasar yang } \\
\text { menghasilkan kata baru }\end{array}$ & mata-mata \\
\hline $\begin{array}{l}\text { Reduplikasi } \\
\text { idiomatis }\end{array}$ & $\begin{array}{l}\text { Pukangulangan kata dasar yang tidak } \\
\text { mengubah makna dasar }\end{array}$ & kucing-kucing \\
\hline
\end{tabular}

Tabel 1. Jenis-jenis dalam Proses Reduplikasi

Penelitian ini bertujuan untuk mengeksplorasi proses reduplikasi kata benda dalam bahasa Melayu dan Jepang dan mengidentifikasi persamaan dan perbedaan yang ada di kedua bahasa. Sejalan dengan tujuan ini, penelitian ini mencoba menjawab pertanyaan penelitian berikut:

1. Reduplikasi macam apa yang terlibat dalam proses reduplikasi kata benda dalam Bahasa Melayu dan Jepang? 


\section{JOURNAL OF \\ EDUCATION \& \\ LINGUISTICS}

2. Bagaimana bentuk, fungsi, dan distribusi dalam kata benda Bahasa Melayu dan Jepang sebagai hasil dari proses reduplikasi?

Penelitian ini menggunakan metode analisis kontrastif untuk menjawab pertanyaan penelitian di atas. Analisis kontrastif adalah cabang dan teknik linguistik sistematis untuk menentukan persamaan dan perbedaan antara dua atau lebih bahasa (Kazemian dan Hashemi, 2014). Analisis kontrastif terdiri dari tiga langkah: (1) deskripsi; (2) penjajaran; (3) perbandingan (Halliday et al. 1964 dalam Krzeszowski, 1990: 35). Dalam penelitian ini, deskripsi reduplikasi penuh dari kata benda dalam dua bahasa diberikan pertama sebagai Krzeszowski (1990: 35) berpendapat bahwa tidak ada perbandingan yang mungkin tanpa penjelasan sebelumnya dari unsurunsur yang akan dibandingkan dan bahwa semua kajian kontrastif harus didasarkan pada deskripsi materi yang bebas. - hal-hal yang berkaitan dengan bahasa akan dibandingkan. Langkah kedua adalah penyelesaian proses reduplikasi penuh dalam bahasa-bahasa ini yang memungkinkan penentuan apa yang akan dibandingkan dan apakah elemen X dalam satu bahasa sama dengan elemen Y dalam bahasa lain (Krzeszowski 1990: 35). Pada langkah terakhir dari analisis kontrastif, persamaan dan perbedaan antara kedua bahasa diidentifikasi dan disajikan.

Analisis ini akan menerapkan model reduplikasi yang dipelopori oleh Rubino Carl (2005) yang menyatakan bahwa proses ini dapat dipelajari dalam bentuk, fungsi, dan distribusi, dan akan dikaitkan dengan fungsi reduplikasi leksikal yang dapat dipertahankannya. Mempertahankan kelas atau mengubah kelas kata sebagaimana Asmah (2001: 17-35) berpendapat bahwa "Reduplication has a lexical function; that is to say it derives new words from the root-forms." Diskusi akan didistribusikan ke dalam tiga bagian, yaitu klasifikasi reduplikasi dalam bahasa Melayu dan Jepang, pembentukan reduplikasi dalam bahasa Melayu dan Jepang, dan analisis kontrastif dari proses reduplikasi dalam bahasa Melayu dan Jepang. 


\section{Signifikansi Penelitian}

Studi ini dianggap sebagai salah satu studi deskriptif kontrasif yang menyentuh reduplikasi kata benda dalam bahasa Melayu dan Jepang. Analisis kontrastif dalam penelitian ini memiliki fungsi dalam membandingkan reduplikasi atau penggandaan kata-kata yang terkandung dalam bahasa Melayu dan Jepang. Selain bahasa Melayu, orang Jepang juga berbagi bentuk, fungsi, dan distribusi pengetahuan morfologis reduplikasi yang dapat digunakan dalam pembentukan kata-kata.

\section{Klasifikasi Reduplikasi dalam bahasa Melayu dan bahasa Jepang}

Asmah (1975) telah mengkategorikan proses reduplikasi bahasa Melayu menjadi sepuluh kelompok sesuai dengan perubahan morfologis yang terjadi pada setiap kata ketika digandakan. Sementara itu, Hassan Abdullah dan Liaw (1994) telah mengkategorikan struktur morfologi reduplikasi Melayu ke dalam enam kategori berikut:

i. Reduplikasi penuh seperti buku-buku, orang-orang;

ii. Reduplikasi berentak seperti kuih-muih, gunung-ganang;

iii. Pengurangan sebagian seperti kekuda, tetamu;

iv. Reduplikasi mental - seperti turun-temurun, gilang-gemilang;

v. Reduplikasi yang tersirat oleh kata dasar tidak bisa berdiri sendiri kecuali dua kali lipat seperti kura-kura, sia-sia; demikian juga

vi. Reduplikasi ditandai oleh proses inisialisasi, lampiran dan sufiks seperti berbual-bual, kehijau-hijauan, dan buah-buahan.

Sementara itu, (Martin, 1988) menjelaskan bahwa pembentukan kata reduplikasi dalam bahasa Jepang adalah salah satu elemen morfologi Jepang dan sering dikaitkan dengan adanya reduplikasi dalam onomatopoeia. Namun, tidak banyak ahli bahasa mencoba fokus pada struktur morfologis reduplikasi dan jenis kata yang terlibat dalam proses reduplikasi. Berbeda dengan reduplikasi bahasa Melayu yang juga terjadi dalam kata-kata asing, reduplikasi dalam bahasa Jepang hanya dapat diamati dalam bahasa Jepang asli (Martin, 1988). Dalam penelitian ini, hanya reduplikasi dalam kelas kata benda yang 
akan menjadi reduplikasi penuh, reduplikasi parsial, dan reduplikasi berima yang akan difokuskan untuk tujuan penelitian ini.

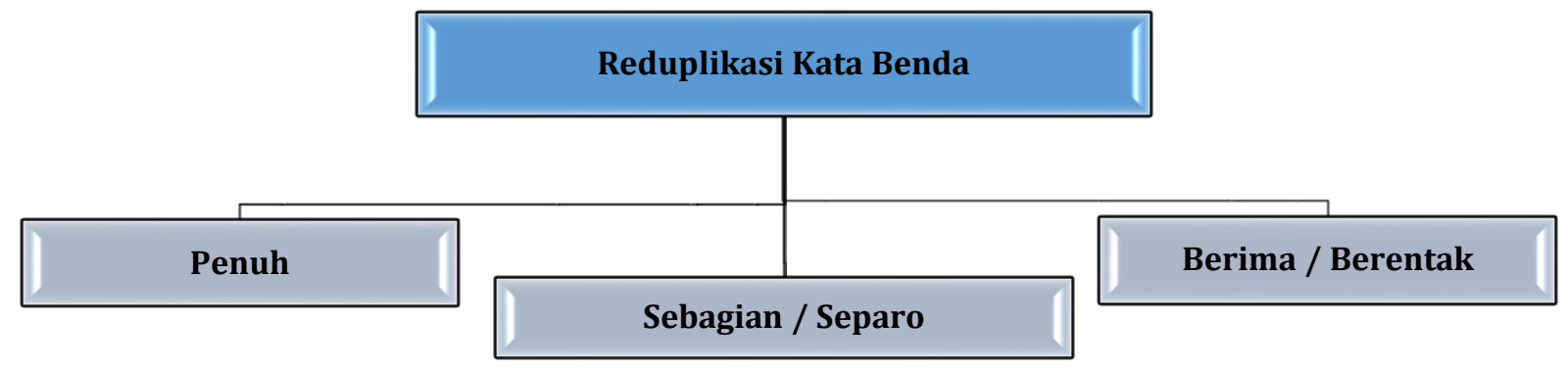

Diagram 1. Tiga Jenis Reduplikasi dalam Kata Benda yang Diberi Fokus

\section{Reduplikasi Kata}

\section{Reduplikasi Kata Benda dalam Bahasa Melayu \\ Bentuk}

Diagram 1 menunjukkan bahwa ada tiga bentuk reduplikasi yang ada dalam bahasa Melayu yaitu reduplikasi penuh, reduplikasi sebagian, dan reduplikasi berima. Reduplikasi penuh terjadi dalam kata benda konkret dan kata benda abstrak dalam bahasa Melayu sebagai orang-orang, budak-budak, fikiranfikiran. Duplikasi penuh ini juga terjadi dalam kata serapan seperti bas-bas, teksi-teksi, hospital-hospital yang digunakan dalam bahasa sehari-hari. Fenomena ini menunjukkan bahwa semua kata benda baik bahasa Melayu asli maskulin atau kata pinjaman akan mengalami proses multiplikasi penuh yang mempertahankan kelas tersebut. Namun, ada juga fenomena multiplikasi kata benda yang mengubah kelas kata-kata seperti pagi-pagi, siang-siang, hati-hati, dan ribut-ribut.

\begin{tabular}{|c|c|c|}
\hline $\begin{array}{c}\text { Bentuk } \\
\text { Reduplikasi }\end{array}$ & $\begin{array}{c}\text { Pengekalan Kelas } \\
\text { Kata }\end{array}$ & Penukaran Kelas Kata \\
\hline Penuh & $\begin{array}{l}\text { rumah-rumah } \\
\text { orang-orang } \\
\text { teknik-teknik } \\
\text { saham-saham }\end{array}$ & $\begin{array}{l}\text { hati-hati } \\
\text { ribut-ribut } \\
\text { hari-hari } \\
\text { pagi-pagi }\end{array}$ \\
\hline Sebagian / Separa & $\begin{array}{l}\text { lelaki } \\
\text { kekura } \\
\text { lelangit }\end{array}$ & \\
\hline
\end{tabular}


pepohon

gunung-ganang

Berima / Berentak

kuih-muih

bukit-bukau

warna-warni

Tabel 2. Pengekalan dan Penukaran Kelas Kata benda Bahasa Melayu dalam Reduplikasi Penuh, Sebagian dan Berima

\section{Fungsi}

Kata reduplikasi adalah reduplikasi penuh, reduplikasi parsial atau bahkan reduplikasi, sebenarnya mendukung makna jamak tetapi reduplikasi ini diperlukan untuk menjelaskan makna jamak ketika kata tersebut tidak digunakan seperti akar $\rightarrow$ akar-akar, kapal terbang $\rightarrow$ kapal-kapal terbang, industry $\rightarrow$ industri-industri. Menurut Abdullah Hassan (1988), ada sepuluh kata yang dapat dibentuk untuk menghasilkan kata binatang dan serangga dengan reduplikasi. Seringkali, hewan dan serangga ini ada dalam kelompok dan banyak dari mereka diberikan dalam reduplikasi seperti anai $\rightarrow$ anai-anai, kupu $\rightarrow$ kupu-kupu, labah $\rightarrow$ labah-labah, rama $\rightarrow$ rama-rama. Variasi reduplikasi lain yang ada dalam bahasa Melayu adalah reduplikasi konsonan (konsonan berirama reduplikasi) seperti pada kuih $\rightarrow$ kuih-muih, lauk $\rightarrow$ laukpauk, sayur $\rightarrow$ sayur-mayur dan juga reduplikasi perubahan vokal (vokal berirama reduplikasi) seperti dalam gunung $\rightarrow$ gunung-ganang, asal $\rightarrow$ asalusul dan lekak $\rightarrow$ lekak-lekuk. Semuanya bekerja dengan makna yang kata itu mengungkapkan banyak makna.

\section{Distribusi}

Bentuk kata benda reduplikasi dalam distribusi bahasa Melayu menunjukkan bentuk kata pinjaman yang sangat kompleks dan produktif yang digandakan untuk menunjukkan retensi dan perubahan kata-kata kelas.

\section{Duplikasi kata dalam bahasa Jepang}




\section{6 tramame of \\ EDUCATION \& \\ LINGUISTICS}

Tsujimura (1996: 148) menganggap proses reduplikasi dalam bahasa Jepang sebagai proses pengulangan sebagian atau seluruh kata untuk menghasilkan kata baru. Reduplikasi yang dikategorikan oleh Tsujimura adalah reduplikasi mimesis seperti gera-gera 'tertawa terbahak-bahak' dan reduplikasi renyoukei seperti naki-naki kaetta 'pulang sambil menangis'. Dalam proses reduplikasi Jepang, semua kategori kata-kata bebas sepenuhnya digandakan baik secara verbal, verbal atau kata sifat dan dapat membentuk kalimat mereka sendiri sebagaimana Yuko Fujimura (2017: 77) menyimpulkan bahwa "any free word, that is, a word which can constitute the sentence on its own is wholly reduplicated."

\section{Bentuk}

Duplikat penuh terjadi dalam kata benda konkret dan abstrak dalam bahasa Jepang seperti yama-yama, mura-mura, ie-ie, yang mempertahankan kelas kata sebagai penanda jamak. Namun, tidak seperti dalam bahasa Melayu, hanya reduplikasi dalam bentuk penuh dan berima yang ada dalam bahasa Jepang

\section{Fungsi}

Kata reduplikasi adalah reduplikasi penuh atau bahkan reduplikasi, sebenarnya mendukung makna jamak. Namun, menurut (Stefan Kaiser, 2001: 346-347) konsep jamak tidak digunakan secara sewenang-wenang dalam bahasa Jepang karena "the way how plurals work in Japanese is that most words do not have plural forms. You cannot say neko-neko for example to mean cats because that word doesn't exist."Ini menunjukkan bahwa meskipun proses reduplikasi ada dalam kata benda Jepang itu terbatas pada kata-kata tertentu saja. Seperti halnya dalam bahasa Melayu, bentuk variasi reduplikasi yang ada dalam bahasa Jepang adalah reduplikasi konsonan (reduplikasi paced konsonan) atau dikenal sebagai rendaku yang berarti "perubahan dalam pelafalan di mana suku kata pertama dari morfem suffiks dapat menjadi diakritik" seperti toki (kala) $\rightarrow$ toki-doki (kadangkala), shima (pulau) $\rightarrow$ shima-jima (banyak pulau) dan hito (orang) $\rightarrow$ hito-bito (ramai orang). 


\begin{tabular}{|c|c|c|}
\hline $\begin{array}{c}\text { Bentuk } \\
\text { Reduplikasi }\end{array}$ & Pengekalan Kelas Kata & Penukaran Kelas Kata \\
\hline Penuh & $\begin{array}{l}\text { ie-ie }(\text { ie } \rightarrow \text { rumah) } \\
\text { mura-mura (mura } \rightarrow \\
\text { kampung) } \\
\text { yama-yama (yama } \rightarrow \text { bukit) } \\
\text { ware-ware (ware } \rightarrow \text { saya) }\end{array}$ & \\
\hline $\begin{array}{l}\text { Sebagian / } \\
\text { Separa }\end{array}$ & & \\
\hline $\begin{array}{l}\text { Berima / } \\
\text { Berentak }\end{array}$ & $\begin{array}{l}\text { hito-bito (hito } \rightarrow \text { orang) } \\
\text { hana-bana (hana } \rightarrow \text { bunga) } \\
\text { kuni-guni (kuni } \rightarrow \text { negara) }\end{array}$ & toki-doki (toki $\rightarrow$ kala) \\
\hline
\end{tabular}

\section{Tabel 3. Pengekalan dan Penukaran Kelas Kata benda Bahasa Jepang dalam Reduplikasi Penuh, Sebagian dan Berima}

\section{Distribusi}

Kata benda reduplikasi yang ada di Jepang menunjukkan distribusi yang sangat terbatas dan tidak seproduktif dalam bahasa Melayu. Kata benda tidak mengalami pinjaman reduplikasi seperti yang terjadi dalam bahasa Melayu.

\section{Reduplikasi Kata Benda dalam bahasa Inggris dan Jepang}

Kajian di atas menunjukkan bahwa kelas kata benda dalam bahasa Melayu sebagai bahasa milik keluarga bahasa Austronesia menggunakan proses reduplikasi karena dalam kata benda reduplikasi sangat produktif, sebagaimana dibuktikan oleh Rubino Carl (2005: 11) yang menyatakan " $a$ language that makes frequent use of full reduplication is the Austronesian language Malay, spoken in the Southeast Asian Region". Proses morfologis ini juga dapat diamati dalam bahasa Jepang di mana beberapa kata dan bukan kata serapan, dapat mengalami reduplikasi. Jumlah kata benda dalam bahasa Jepang yang diduplikasi tidak seproduktif dalam bahasa Melayu, seperti yang 
diperdebatkan oleh Linus Olsson (2015) bahwa "as has been shown in this study, there are indeed a lot of reduplicated words in Japanese among all the word classes. However, the results of this study seem to indicate that reduplication, at least in nouns, is less productive and has a more restricted usage than in many other languages of the world." Namun, perbandingan ini menunjukkan bahwa bahasa Melayu dan Jepang mendukung beberapa kesamaan kecil hasil dari proses reduplikasi kelas kata benda, yaitu

i. mendukung konsep jamak dengan reduplikasi kata benda seperti rumah-rumah dan ie-ie;

ii. konversi kelas kata juga terjadi sebagai hasil dari reduplikasi kata benda seperti hati $\rightarrow$ hati-hati dalam bahasa Melayu dan toki (kala) $\rightarrow$ toki-doki (kadangkala) dalam bahasa Jepang; dan

\begin{tabular}{|c|c|c|c|c|}
\hline \multirow{2}{*}{$\begin{array}{c}\text { Bentuk } \\
\text { Reduplikasi }\end{array}$} & \multicolumn{2}{|c|}{ Pengekalan Kelas Kata } & \multicolumn{2}{|c|}{ Penukaran Kelas Kata } \\
\hline & $\begin{array}{l}\text { Bahasa } \\
\text { Melayu }\end{array}$ & $\begin{array}{l}\text { Bahasa } \\
\text { Jepang }\end{array}$ & $\begin{array}{l}\text { Bahasa } \\
\text { Melayu }\end{array}$ & BahasaJepang \\
\hline Penuh & $\begin{array}{l}\text { rumah- } \\
\text { rumah } \\
\text { orang-orang } \\
\text { teknik- } \\
\text { teknik } \\
\text { saham- } \\
\text { saham }\end{array}$ & $\begin{array}{l}\text { ie-ie } \\
\text { mura-mura } \\
\text { yama-yama } \\
\text { ware-ware }\end{array}$ & $\begin{array}{l}\text { hati-hati } \\
\text { ribut-ribut } \\
\text { hari-hari } \\
\text { pagi-pagi }\end{array}$ & \\
\hline $\begin{array}{l}\text { Sebagian / } \\
\text { Separa }\end{array}$ & $\begin{array}{l}\text { lelaki } \\
\text { kekura } \\
\text { lelangit } \\
\text { pepohon } \\
\end{array}$ & & & \\
\hline $\begin{array}{l}\text { Berima / } \\
\text { Berentak }\end{array}$ & $\begin{array}{l}\text { gunung- } \\
\text { ganang } \\
\text { kuih-muih } \\
\text { bukit-bukau } \\
\text { warna- } \\
\text { warni }\end{array}$ & $\begin{array}{l}\text { hito-bito } \\
\text { hana-bana } \\
\text { kuni-guni }\end{array}$ & & toki-doki \\
\hline
\end{tabular}

Tabel 4. Kontrastif Pengekalan dan Penukaran Kelas Kata benda Bahasa Melayu dan Bahasa Jepang dalam Reduplikasi Penuh, Sebagian dan Berima 
iii. variasi lain dari reduplikasi yang ada dalam bahasa Melayu yaitu reduplikasi konsonan (reduplication paced consonant) dan pada Bahasa Jepang yaitu proses rendaku yang memperlihatkan perubahan suara konsonan pada morfem baik ketika direduplikasi seperti kuihmuih dalam bahasa Melayu dan hito-bito dalam bahasa Jepang, yang secara tidak langsung menunjukkan satu pola reduplikasi berima dalam kedua bahasa, sebagaimana Rubino (2005: 11) menunjukkan bahwa "words can be created with reduplication in several different ways, for example by repeating a part of the beginning, end, or inside of the simplex form, or by other means such as consonant gemination or vowel lengthening."

\begin{tabular}{|c|c|}
\hline $\begin{array}{l}\text { Bentuk } \\
\text { Reduplikasi }\end{array}$ & Analisis Kontrastif \\
\hline Penuh & $\begin{array}{l}\text { Kedua-dua kata benda dalam bahasa Melayu dan bahasa } \\
\text { Jepang mengalami reduplikasi penuh. Namun, proses } \\
\text { morfologi ini adalah sangat produktif dalam bahasa Melayu } \\
\text { dan juga berlaku pada kata-kata serapan yang ada dalam } \\
\text { bahasa Melayu. Hanya kata-kata benda terpilih saja yang } \\
\text { direduplikasikan dalam bahasa Jepang dan hanya ada dalam } \\
\text { kata asli bahasa Jepang. }\end{array}$ \\
\hline $\begin{array}{l}\text { Sebagian } \\
\text { Separa }\end{array}$ & $\begin{array}{l}\text { Kata-kata benda dalam bahasa Melayu juga ada dalam } \\
\text { bentuk reduplikasi sebagian atau separa. Bentuk ini tidak } \\
\text { kelihatan dalam bahasa Jepang. }\end{array}$ \\
\hline $\begin{array}{l}\text { Berima / } \\
\text { Berentak }\end{array}$ & $\begin{array}{l}\text { Kedua-dua kata benda dalam bahasa Melayu dan bahasa } \\
\text { Jepang mengalami reduplikasi berima atau berentak. Dalam } \\
\text { bahasa Jepang, ini memperlihatkan perubahan konsonan /h/ } \\
\text { menjadi /b/ dalam suku kata pertamanya, yang dapat } \\
\text { dikategorikan sebagai reduplikasi dengan perubahan bunyi. } \\
\text { Proses ini dikenali sebagai proses rendaku. Sementara dalam } \\
\text { bahasa Melayu, adanya perubahan bunyi konsonan seperti } \\
\text { dalam lauk-pauk, di mana /l/ menjadi /p/ ataupun dalam } \\
\text { sayur-mayur /s/menjadi /m/ ketika dijamakkan. }\end{array}$ \\
\hline
\end{tabular}

Tabel 5. Ringkasan Kontrastif yang ada dalam Bahasa Melayu dan Bahasa Jepang 


\section{KESIMPULAN}

Fenomena reduplikasi kata benda dari bahasa Melayu dan Jepang yang dibahas di atas mencoba menunjukkan bentuk reduplikasi yang ada dalam bahasa Melayu dan Jepang. Hasilnya membuktikan ada kesamaan dan perbedaan signifikan yang terdapat dalam bahasa Melayu dan Jepang. Dengan kata lain, analisis di atas menunjukkan proses reduplikasi dalam bahasa Melayu dan Jepang dari pola morfologis bila dibandingkan secara sistematis.

Hasil kontrastif bahasa Melayu dan Jepang di atas, dapat disimpulkan bahwa berkenaan dengan proses reduplikasi kata benda, kedua bahasa berbagi beberapa kesamaan dan banyak perbedaan. Dapat dilihat bahwa tidak semua kelas kata benda dalam bahasa Melayu dan Jepang mengalami semua proses reduplikasi. Dalam bahasa Melayu, proses reduplikasi kata benda ada dalam semua bentuk reduplikasi termasuk kata-kata serapan. Dalam bahasa Jepang, hanya proses reduplikasi penuh dan final yang kurang produktif. Mengenai fungsi kata-kata baru yang dihasilkan sebagai hasil dari proses reduplikasi di kedua bahasa, kata-kata baru dapat mempertahankan atau mengubah jenis kelas kata-kata mereka. Dalam bahasa Melayu berlaku untuk semua bentuk reduplikasi penuh dan reduplikasi kata berima dalam bahasa Jepang sementara itu hanya reduplikasi kata sifat yang diamati dalam bentuk berima.

\section{REFERENSI}

Aronoff, M., \& Fudeman, K. (2005). What is morphology? Oxford: Blackwell Publishing.

Chen, K. (1997). English vs Chinese: World views and writing styles. TESOL Matters, 7, 1-13.

Crystal, D. (1992). An encyclopedic dictionary of language and languages. London: Blackwell Publishers. 
Crystal, D. (2003a). A dictionary of linguistics and phonetics (5 ${ }^{\text {th }}$ ed.). London: Blackwell Publishing.

Crystal, D. (2003b). The Cambridge encyclopedia of the English language (2 $^{\text {nd }}$ ed.). London: Cambridge University Press.

Crystal, D. (2007). How language works. London: The Penguin Group.

Fisiak, J. (1981). Contrastive linguistics and the language teacher. New York: Pergamon.

Flick, U. (2010). An introduction to qualitative research. London: Sage Publication Inc.

Fries, C. C. (1945). Teaching and learning English as a foreign language. Michigan: University of Michigan Press.

Fujimura, Y. (2001). Reduplication in standard Malay and Japanese. Journal of Modern Languages, 13(1), 65-92.

Hamzah, Z. A. Z., \& Talif, R. (2010). Kepentingan analisis kontrastif dalam pengajaran dan pembelajaran bahasa. Pancadimensi Pengajaran dan Pembelajaran Bahasa: Trend dan Amalan. Pulau Pinang: Penerbit Universiti Sains Malaysia.

Hassan, A. (1974). The morphology of Malay. Kuala Lumpur: Dewan Bahasa dan Pustaka.

James, C. (1981). Contrastive analysis. Harlow: Longman.

Kaplan, R. (1966). Cultural thought patterns in intercultural education. Language Learning, 16, 1-20. Retrieved from http://dx.doi.org/10.1111/j.1467-1770.1966.tb00804.x (Accessed 20 March 2019)

Karim, Nik Safiah, et al. (2015). Tatabahasa dewan edisi ketiga. Kuala Lumpur: Dewan Bahasa dan Pustaka.

Katamba, F. (1993). Morphology. Houndmills, Basingstoke: Macmillan Press.

Kauffman, C. A. (n.d.). Reduplication reflects uniqueness and innovation in language, thought and culture. York College of Pennsylvania.

Lado, R. (1957). Linguistics across culture: Applied linguistics for language teaching. Michigan: University of Michigan Press. 


\section{JOURNAL OF \\ EDUCATION \& \\ LINGUISTICS}

Liaw \& Abdullah. (1994). Nahu Melayu moden. Kuala Lumpur: Penerbit Fajar Bakti.

Martin, S. (1988). Reference grammar of Japanese. Yale: Yale University Press.

Morioka, K. (1994). Keitaisoron. Gokousei, 57-87. Tokyo: Hitsuji Shobou.

Nadarajan, S. (2006). A crosslinguistic study of reduplication. The Arizona Working Papers in Second Language Acquisition and Teaching, 13, 39-53.

Nomoto, H. (2012). Consonant-changing reduplication in Malay as identity avoidance. Proceedings of the 19th Annual Meeting of the Austronesian Formal Linguistics Association.

Olsson, L. (2015). Form and function of reduplicated nouns in Japanese. Unpublished Master Dissertation. Stockholms Universitet.

Omar, A. H. (1975). Reduplication. Essays on Malaysian linguistics, 185-223. Kuala Lumpur: Dewan Bahasa dan Pustaka.

Omar, A. H. (2001). Languages and language situation of Southeast Asia. Jurnal Bahasa Moden, 13, 17-35. Kuala Lumpur: Fakulti Bahasa dan Linguistik.

Omar, A. H. (2008). Ensiklopedia bahasa Melayu. Kuala Lumpur: Dewan Bahasa dan Pustaka.

Ringbom, H. (1994). Contrastive analysis. In Asher, R. E., \& Simpson, J. M. Y. (Ed). Encyclopedia of Linguistics, 2, 737-742. Oxford: Permagon Press.

Rubino Carl. (2005). Reduplication: Form, function and distribution. In Hurch, B. (Ed). Studies on Reduplication, 11-29. Berlin: Walter de Gruyter.

Shibatani, M. (1990). Japanese. The World's Major Languages, 855-880. Oxford: Oxford University Press.

Stern, H. H. (1983). Fundamental concepts of language teaching. Oxford: Oxford University Press.

Tamamura, F. (1986). Kodai ni okeru wago meishi no tatamigo ni tsuite. Nihongo Kenkyuu, 220 - 238. Tokyo: Meiji Shoin

Uzawa, H. (2012). Analysis and synthesis of the semantic functions of reduplication in Malay. Corpus-based Linguistics and Language Education, 9, 185-202. 


\section{VOL. 4, NO. 1 \\ FEBRUARI 2020}

Wahab, M. A. H. A. (1989). Bahasa Malaysia baku KBSM. Petaling Jaya: SASBADI Sdn. Bhd.

Weinreich, V. (1953). Languages in contact. New York: Linguistic Circles of New York.

\section{Privacy Statement}

** Paper ini telah dipresentasikan di International Language and Education Conference (iLEC) 2019, anjuran bersama Fakulti Pengajian Bahasa-Bahasa Utama, Universiti Sains Islam Malaysia (USIM) dan Fakultas Pendidikan Bahasa, Universitas Muhammadiyyah Yogyakarta (UMY), di Sama-Sama Hotel, Sepang, Selangor Darul Ehsan, pada 9 dan 10 Oktober 2019. 